Article

\title{
The Heterogeneous Aminohydroxylation Reaction Using Hydrotalcite-Like Catalysts Containing Osmium
}

\author{
Mohamed I. Fadlalla ${ }^{1,2}$, Glenn E. M. Maguire ${ }^{1}$ and Holger B. Friedrich ${ }^{1, *(1)}$ \\ 1 School of Chemistry and Physics, University of KwaZulu-Natal, Durban 4041, South Africa; \\ Mohamed.fadlalla@uct.ac.za (M.I.F.); maguireg@ukzn.ac.za (G.E.M.M.) \\ 2 Catalysis Institute, Department of Chemical Engineering, University of Cape Town, Rondebosch 7701, \\ South Africa \\ * Correspondence: friedric@ukzn.ac.za; Tel.: +27-(0)31-260-3107
}

Received: 30 September 2018; Accepted: 30 October 2018; Published: 16 November 2018

\begin{abstract}
The aminohydroxylation reaction of olefins is a key organic transformation reaction, typically carried out homogeneously with toxic and expensive osmium (Os) catalysts. Therefore, heterogenisation of this reaction can unlock its industrial potential by allowing reusability of the catalyst. Os- $\mathrm{Zn}-\mathrm{Al}$ hydrotalcite-like compounds (HTlcs), as potential heterogeneous aminohydroxylation catalysts, were synthesised by the co-precipitation method and characterised by several techniques. Reaction parameters (i.e., solvent system, reaction temperature, and catalyst structure) were optimized with cyclohexene, styrene, and hexene as substrates. The different classes of olefins (aliphatic, aromatic, and functionalised) that were tested gave $>99 \%$ conversion and high selectivity $(>97 \%)$ to the corresponding $\beta$-amino alcohol. The catalyst HTlc structure had a significant effect on the reaction time and yield of the $\beta$-amino alcohols. Under the same testing conditions, a heat treated catalyst (non-HTlc) showed a shorter reaction time, but drop in the yield of $\beta$-amino alcohols and rise in diol formation was observed. Leaching tests showed that $2.9 \%$ and $3.4 \%$ of Os (inactive) leached from the catalyst to the reaction solution when $\mathrm{MeCN} /$ water $(1: 1 v / v)$ and $t$ - $\mathrm{BuOH} /$ water $(1: 1 v / v)$, respectively, were used as the solvent system. Recycling studies showed that the catalyst can be reused at least thrice, with no significant difference in the yield of the $\beta$-amino-alcohol.
\end{abstract}

Keywords: aminohydroxylation; heterogeneous catalysis; hydrotalcite-like compounds; leaching and recyclability study

\section{Introduction}

Olefins are considered one of the most important starting materials in organic synthesis. They are cheap and widely available, and the double bond allows 1,2-functionalisation via face selective oxidation [1,2]. For example, olefins are utilised as starting materials to produce diols and vicinal amino alcohols during the dihydroxylation $(\mathrm{DH})$ and aminohydroxylation $(\mathrm{AH})$ reaction, respectively. Both reactions (i.e., $\mathrm{DH}$ and $\mathrm{AH}$ ) are catalysed by $\mathrm{OsO}_{4}$ and are considered to be highly selective and reliable organic transformations, because $\mathrm{OsO}_{4}$ reacts with a wide spectrum of olefins and does not react or reacts very slowly with other organic functional groups present [3]. The $\mathrm{AH}$ reaction has been studied extensively by Sharpless et al. [4,5], and more recently, considerable interest has focused on the $\mathrm{AH}$ reaction, as $\beta$-amino alcohols are an important functionality in chiral ligands and biologically active compounds [6]. $\beta$-Amino alcohols are classified into three general groups, including (i) naturally occurring compounds, (ii) synthetic pharmacologically active molecules, and (iii) chiral ligands [7-9].

The homogeneous asymmetric aminohydroxylation reaction uses both osmium and, usually, a cinchona alkaloid ligand, both of which are relatively expensive components when trying to scale up the reaction. Furthermore, osmium is a toxic metal, hence there have been investigations on the 
aminohydroxylation reaction using non-toxic or less toxic metals such as iron and copper [10,11]. There have been several attempts at heterogenising the asymmetric aminohydroxylation reaction (using osmium) to allow the re-use of these components. One approach was by supporting the 1,4-bis(9-O-quininyl)phthalazine $\left((\mathrm{QN})_{2} \mathrm{PHAL}\right)$ ligand on silica gel [12]. The results obtained with this method showed percentage yields of $\beta$-amino alcohols ranging from 30 to $81 \%$ (based on the nature of the olefin) and enantiomeric excess (ee) values ranging from 88 to $>99 \%$. However, this system resulted in osmium leaching into the product and the addition of osmium was required to restore the original activity [12].

A different approach was to support the $(\mathrm{QN})_{2} \mathrm{PHAL}$ on a polymer, which resulted in percentage conversions to $\beta$-amino alcohols ranging from 73 to $98 \%$ and $e e$ ranging from 83 to $87 \%$. However, upon recycling of the catalyst, the percentage conversion reduced to $58 \%$ and the $e e$ value to $81 \%$ [13]. Unlike the silica supported catalyst, the activity was not restored by further addition of osmium.

The latest approach to heterogenising this reaction involved supporting $\mathrm{OsO}_{4}$ on a layered double hydroxide (LDH). This resulted in yields of $\beta$-amino alcohols ranging from 45 to $55 \%$ and $e e$ values ranging from 40 to $78 \%$. However, high levels of osmium leaching were observed. The authors suggested that this could be the result of the high polarizing effect of chloramine-T that was used as the nitrogen source [14].

Previous studies, apart from also forming diol by-products, have two facts in common, osmium leaching and the reasonable to excellent enantiomeric excess attained. Furthermore, the approaches that heterogenise the ligand do not immobilise the osmium $[12,13]$. Therefore, the problem of heterogenising the osmium remains, which is the focus of this study.

Hydrotalcite (HT) and hydrotalcite-like compounds (HTlcs) are examples of anionic clays and can be defined as layered, positively charged brucite-like structures in which the net charge is balanced by anions in the interlayer [15,16]. HT consists of hydroxyl-carbonates of aluminum and magnesium [12,17]. Since their discovery in 1842, hydrotalcites are also referred to as layered double hydroxides [12,16-18]. HTlcs are compounds that consist of metals other than aluminum and magnesium, but exhibit the same structure as a hydrotalcite [16]. HTlcs can be tailored for specific catalytic application by changing the elements and the ratio in which they are present. Furthermore, the active cations can be isomorphically substituted with $\mathrm{Mg}^{2+}$ or $\mathrm{Al}^{3+}$ in the octahedral site.

Previous research on the use of Os-HTlc catalysts in the heterogenization of the dihydroxylation reaction [19] showed that they have activity, selectivity, and catalyst stability. These results inspired us to utilize the Os-HTlc system for the current study of the heterogenization of the aminohydroxylation reaction. This study thus focused on heterogenising the aminohydroxylation reaction by incorporating osmium as part of a hydrotalcite-like structure. The effects of different conditions (temperature and solvent system), the catalyst crystallinity, and structure were examined.

\section{Results}

\subsection{Catalyst Characterization}

The Os-HTlc catalyst was prepared via the co-precipitation method with a target ratio of $0.3 \mathrm{Os} / \mathrm{Al}$, based on previously reported studies $[19,20]$. The catalyst characterisation focused on determining the metal content, phase composition, surface area, and metal distribution in the catalysts. The three metals present (Os, $\mathrm{Zn}$, and $\mathrm{Al}$ ) in the prepared materials were quantitatively determined by means of inductively coupled plasma optical emission spectroscopy (ICP-OES) (Table 1). In catalyst A, the ratio of osmium to aluminum was close to the target of 0.3 . This ratio is reported to give a HTlc structure [19]. Furthermore, the ratio of $0.3 \mathrm{Os} / \mathrm{Al}$ gave a catalyst with good activity in the dihydroxylation reaction, as previously reported [20]. However, the ratio of zinc to aluminum was slightly higher than the target value of 3 . After the heat treatment at $300^{\circ} \mathrm{C}$ for two hours of catalyst $\mathrm{A}$, to give catalyst $\mathrm{B}$, the osmium content decreased by $42 \%$, which was likely the result of sublimation. As a consequence the HTlc structure collapsed, which resulted in a mixed metal oxide. 
The powder XRD pattern for the crystalline HTlc (Figure 1a) is characterised by several high intensity peaks at low $2 \theta$ values. As the values for $2 \theta$ increase, the intensity of the peaks decreases, in the plane order of 003 to 110. The equal spacing between planes 003 and 006 , and 006 and 012 , indicate the stacking order of the HTlc's. HT and HTlc's have a hexagonal plane, which is the 110 plane, shown by a doublet peak at high $2 \theta$ value and low intensity. The presence of a hydroxide in the material is indicated by a peak with a d-spacing of $11.1 \AA$. The sharpness of the peaks is indicative of the crystallinity of the catalyst. The XRD pattern of catalyst $B$ (Figure $1 b$ ) showed that the compound did not maintain the HTlc structure after heating. This is indicated by the absence of all the characteristic features in the pattern expected of the HTlc. The XRD pattern (Figure 1b) shows that there is no crystalline HTlc phase present. According to literature, osmium can migrate to the surface upon heating, which was evident in HRTEM [20]. Furthermore, calcination of the hydrotalcite-like compound at $300{ }^{\circ} \mathrm{C}$ can result in the presence of both the HT phase and the metal oxide phase [21]. Possibly, in part, as a result of the low crystallinity of the heat-treated catalyst, this was not observed for catalyst $B$.

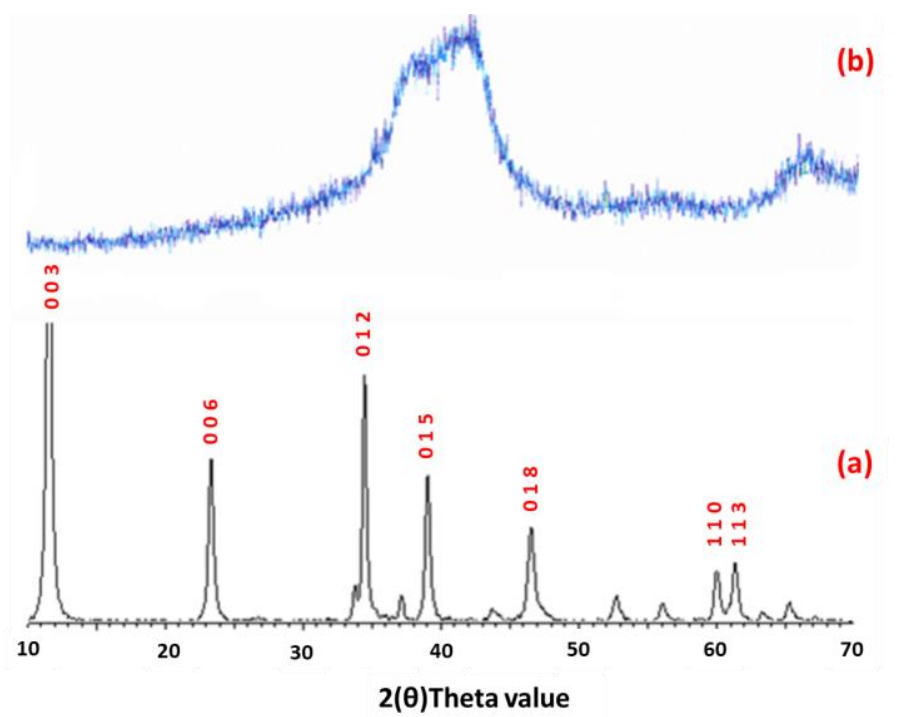

Figure 1. XRD pattern of Os-hydrotalcite-like compound (HTlc) (a) and Os-HTlc treated at $300{ }^{\circ} \mathrm{C}$ (b) obtained with Cu source $(\lambda=1.5406 \AA)$.

Table 1. Chemical and physical properties of temperature (un)treated Os-HTlc prepared by co-precipitation for the aminohydroxylation reaction of olefins.

\begin{tabular}{|c|c|c|c|c|c|}
\hline Catalyst & Crystallite Size/Å & a Parameter/Å & $c$ Parameter/Å & $\begin{array}{c}\text { BET-SURFACE } \\
\text { Area } / \mathrm{m}^{2} \mathrm{~g}^{-1}\end{array}$ & $\begin{array}{c}\text { ICP-OES of } \\
\text { Os/Zn/Al }\end{array}$ \\
\hline Catalyst A & 196 & 3.06 & 23.09 & 87 & $0.29 / 3.5 / 1$ \\
\hline Catalyst B & - & - & - & 150 & $0.17 / 3.56 / 1$ \\
\hline
\end{tabular}

The surface morphology of catalyst A and the distribution of the three metals in the catalyst was investigated by means of scanning electron microscopy (SEM) and electron dispersion spectroscopy, respectively. The SEM images of catalyst A (Figure 2a) show that the catalyst is crystalline, which correlates with the XRD results mentioned previously. As the sample was ground and selected randomly for the EDS analysis, one can assume that the sample is homogeneous. More importantly, EDS images show that osmium is homogeneously distributed in the HTlc (Figure 2b), with no agglomeration detected, which further confirms that osmium is part of the catalyst structure and not just supported on the HTlc. 
(a)

(b)
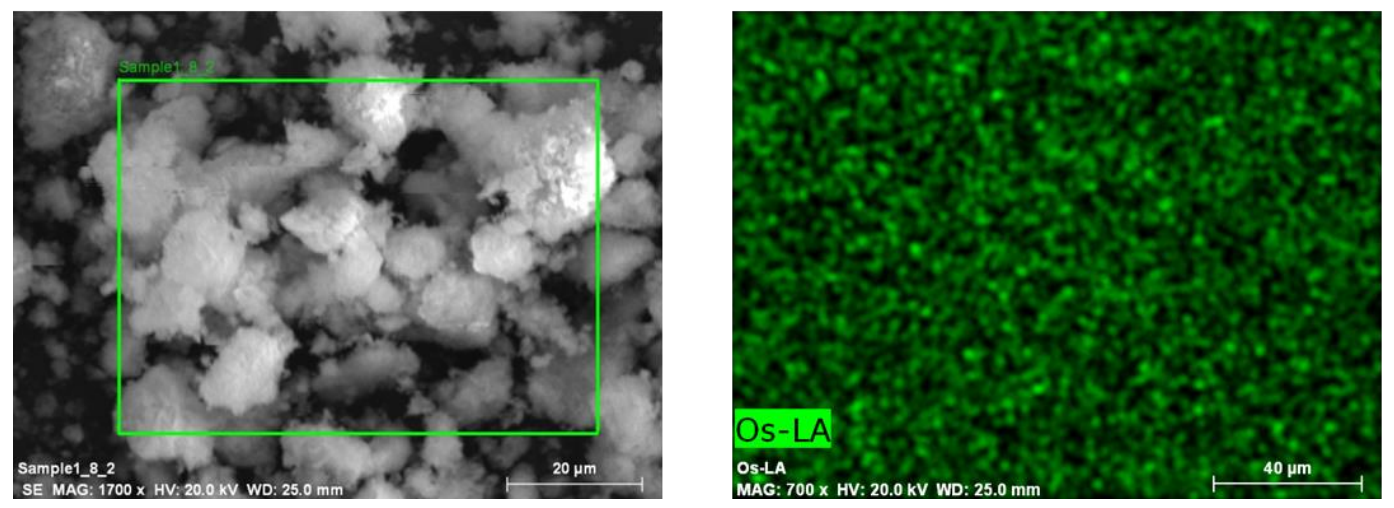

Figure 2. Surface morphology of Os-HTlc (a) and EDX mapping of Os in the Os-HTlc catalyst (b).

\subsection{Catalytic Testing}

The next step focused on investigating the Os-HTlc catalyst performance in the aminohydroxylation reaction (Scheme 1) as a function of reaction solvent, temperature, catalyst structure, and finally the suitability of the catalyst in the aminohydroxyation of different olefins at the optimal conditions.
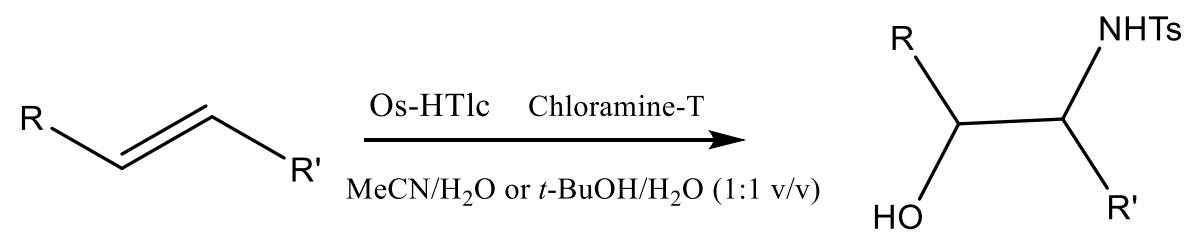

Scheme 1. Heterogeneous aminohydroxylation reaction over Os-hydrotalcite-like compound (HTlc) at $25^{\circ} \mathrm{C}$ with chloramine- $\mathrm{T}$ as nitrogen source (Ts $=$ tosyl group).

\subsubsection{Effect of Solvent on Reaction Time}

The solvents that were chosen for this study (i.e., toluene, $\mathrm{MeCN} /$ water $(1: 1 v / v)$, and $t-\mathrm{BuOH} /$ water $(1: 1 v / v))$ display a wide range of polarities [22]. The results obtained (Figure 3) show that the reaction time increases in the following order: $\mathrm{MeCN} /$ water $(1: 1 v / v) \approx t$ - $\mathrm{BuOH} /$ water $(1: 1 v / v)<$ toluene, and the dielectric constants for these solvents decrease in the same order.

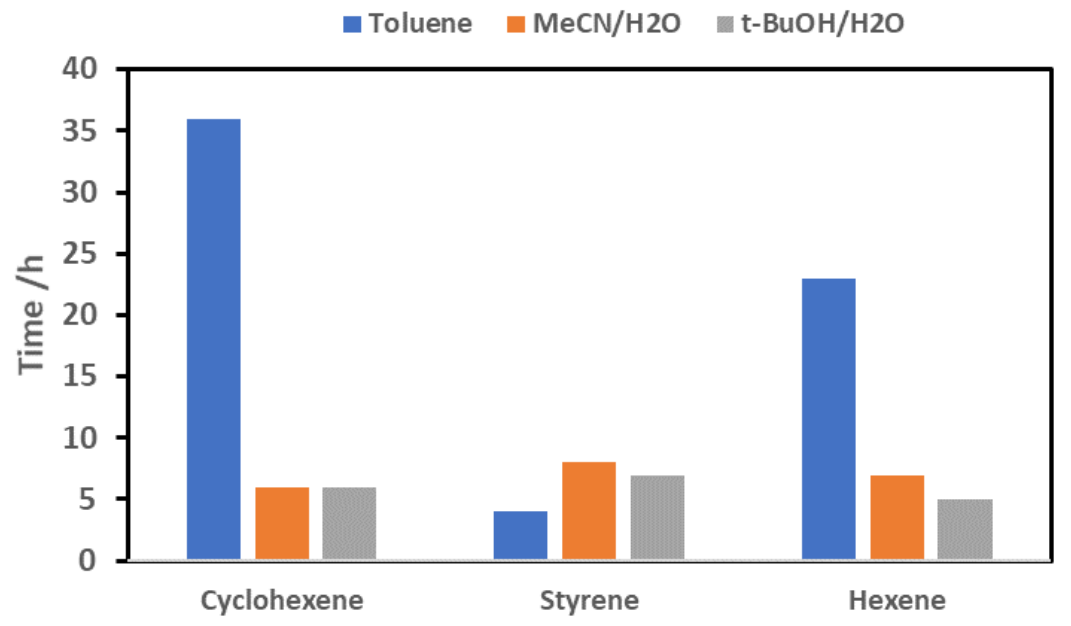

Figure 3. Effect of the solvent system on the reaction time for $99.99 \%$ conversion of the olefin determined by gas chromatograph (GC), using chloramine-T as the nitrogen source and catalyst $\mathrm{A}$ at $60{ }^{\circ} \mathrm{C}$. 


\subsubsection{Effect of Temperature on Reaction Time}

This investigation was carried out at temperatures of $25^{\circ} \mathrm{C}$ and $60{ }^{\circ} \mathrm{C}$ using the three solvent systems and styrene as model olefin (Figure 4). Temperature did not have a significant effect on either reaction time or product distribution when $\mathrm{MeCN} /$ water and $t-\mathrm{BuOH} /$ water $(1: 1 v / v)$ were used. Only trace amounts of the diol were detected when these two solvent systems were employed with catalyst A. In the case of toluene, the reaction time decreased with an increase in reaction temperature up to $60{ }^{\circ} \mathrm{C}$. This is possibly the result of the fact that chloramine- $\mathrm{T}$ is completely soluble in MeCN/water and $t-\mathrm{BuOH} /$ water $(1: 1 v / v)$, but is only partially soluble in toluene. Thus, an increase in the reaction temperature increases the solubility and hence decreases the reaction time.

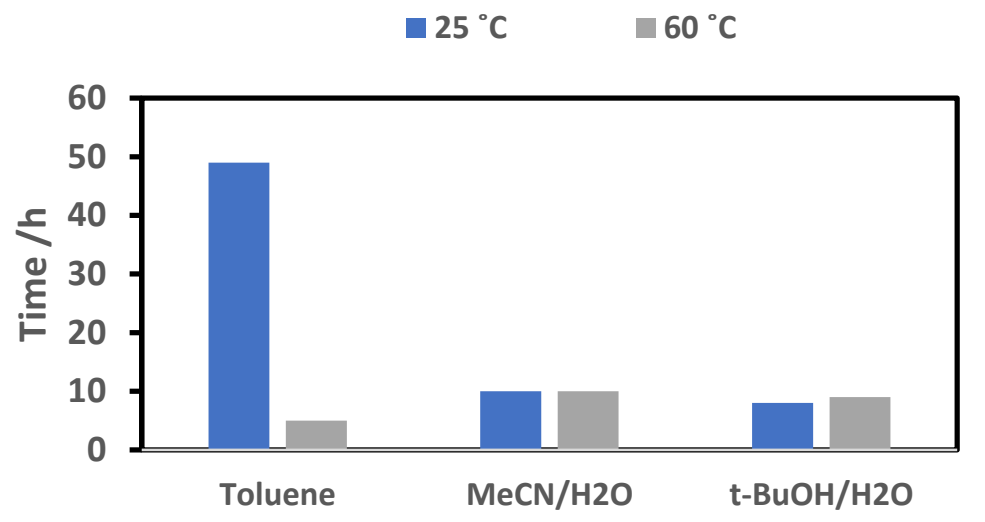

Figure 4. Effect of temperature on reaction time (complete depletion of starting material), using styrene, chloramine-T as the nitrogen source, and catalyst A.

\subsubsection{Effect of Catalyst Structure on Reaction Time}

The comparison between the HTlc (catalyst A) and the mixed metal oxide (catalyst B) in the aminohydroxylation reaction should aid in understanding to what extent the structure of the HTlc is necessary for catalytic activity in this reaction, as literature has shown that the HTlc structure is important for a number of reactions $[19,20]$. Thus, catalyst B, which had lost the HTlc structure, was also studied to investigate the effect of heat treatment on catalytic activity. These experiments were carried out utilizing cyclohexene and $t$-butylcrotonate as the model olefins with MeCN/water $(1: 1 v / v)$ as the solvent system. The reaction time for cyclohexene was $6 \mathrm{~h}$ and $3 \mathrm{~h}$, over catalysts A and B, respectively, while for $t$-butylcrotonate, the reaction time was ca. $22 \mathrm{~h}$ over both catalysts. However, the selectivity to $\beta$-amino alcohols dropped and selectivity to diols increased over catalyst $B$.

\subsubsection{Screening of Different Classes of Olefins}

The olefins utilized in this study allow the investigation of alkene nature and steric effects on the reaction time and the yield (Scheme 1, Table 2). The substrates can be divided into aliphatic, aromatic, and functionalised olefins. All the reactions were carried out at $25^{\circ} \mathrm{C}$.

The reaction time was observed to be shorter for the aliphatic olefins than for the functionalised ones, with hexene having the shortest reaction time and cis-stilbene, methylcinnamate, and dimethylfumarate having the longest reaction times. Furthermore, the two solvent systems show comparable reaction times for the same substrate. Similar observations were reported in the homogeneous reaction $[13,14]$. Selectivity to the aminohydroxylation products exceeds $99 \%$ in all cases. 
Table 2. Reaction time and high performance liquid chromatograph (HPLC) yield percentage for the different olefins used in the aminohydroxylation reaction catalysed by the HTlc catalyst containing osmium at $25^{\circ} \mathrm{C}$.

\begin{tabular}{|c|c|c|c|}
\hline Entry & Olefin & $\begin{array}{c}\text { Reaction Time/h in } \\
\mathrm{MeCN} / \mathrm{H}_{2} \mathrm{O}\left(t-\mathrm{BuOH} / \mathrm{H}_{2} \mathrm{O}\right)\end{array}$ & $\begin{array}{l}\text { \% Yield of } \beta \text {-Amino Alcohol, } \text {, } \\
\text { in } \mathrm{MeCN} / \mathrm{H}_{2} \mathrm{O}\left(t-\mathrm{BuOH} / \mathrm{H}_{2} \mathrm{O}\right)\end{array}$ \\
\hline 1 & & $7(8)$ & 99 (99) \\
\hline 2 & & $9.5(10)$ & 99 (99) \\
\hline 3 & & $7(6)$ & 99 (99) \\
\hline 4 & & $24(24)$ & 99 (99) \\
\hline 5 & & $23(24)$ & 99 (99) \\
\hline 6 & & $24(24)$ & 99 (99) \\
\hline 7 & & $22(23)$ & 99 (99) \\
\hline
\end{tabular}

\subsection{Leaching Test}

For the reaction to be strictly heterogeneous, the active species must not leach into the reaction mixture, or, if they leach, their homogeneous form must not be catalytically active [23]. To determine if the reaction is heterogeneous, catalyst A was removed after approximately $20 \%$ of the cyclohexene had reacted (after $2 \mathrm{~h}$ ) at $25{ }^{\circ} \mathrm{C}$. The reaction mixture (without the catalyst) was allowed to stir for a further $6 \mathrm{~h}$. ICP analysis of the solution showed that osmium does leach, to a small degree, but not in an active form, as gas chromatograph (GC) analysis of the solution showed no further starting material depletion after removal of the catalyst. The amounts of osmium leached from catalyst $\mathrm{A}$ in $\mathrm{MeCN} /$ water and $t-\mathrm{BuOH} /$ water was similar at $2.9 \%$ and $3.4 \%$, respectively. This effect could be the result of the strong polarizing effect of chloramine-T [14].

An important result of this work over that previously reported [12-14,24] is that the lowest level of inactive osmium leaching to the reaction mixture was observed. Previous attempts at heterogenisation of the aminohydroxylation reaction had shown leaching ranging from 20 to $50 \%$ [12].

\subsection{Recycling Test}

One of the main advantages of heterogeneous over homogeneous catalysis is that the catalyst can be (easily) recycled a number of times [25]. The results for the recycling test showed that the reaction time increases slightly with an increase in the number of recycles (Table 3). 
Table 3. Reaction time and percentage yield of the $\beta$-amino alcohols of cyclohexene with respect to the cycle number.

\begin{tabular}{ccc}
\hline Recycle Number & Reaction Time/h & Conversion/Yield \% * \\
\hline 1 & 7 & $>99$ \\
2 & 7.5 & $>99$ \\
3 & 8.5 & $>99$ \\
\hline
\end{tabular}

* determined by HPLC.

\subsection{Spent Catalyst Characterisation}

The XRD diffractogram of the spent catalyst (Figure 5) shows that the catalyst is still indeed a hydrotalcite-like compound after the aminohydroxylation reaction. The low count in the XRD diffractogram could be the result of the spent catalyst losing some of its crystallinity during the course of the reaction. ICP analysis (Table 4) showed the amount of osmium and zinc had decreased after the reaction, which indicates leaching from the catalyst structure to the reaction mixture.

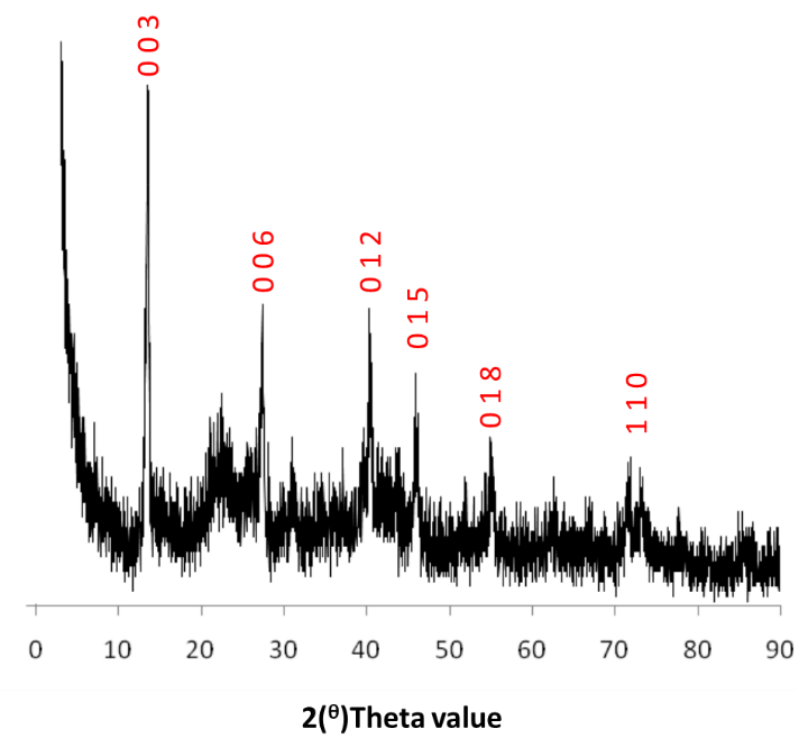

Figure 5. XRD of Os-HTlc used in the aminohydroxylation reaction at $25^{\circ} \mathrm{C}$ and chloramine-T as nitrogen source.

Table 4. The metal ratio in the catalyst before and after the reaction, as determined by ICP-OES analysis.

\begin{tabular}{cccc}
\hline Catalyst & Os & Zn & Al \\
\hline Before reaction & 0.31 & 3.70 & 1.00 \\
After reaction & 0.22 & 3.50 & 1.00 \\
\hline
\end{tabular}

\section{Discussion}

The average distance between the cations (in the brucite-like structure) can be represented by the a parameter, calculated using the $d$-spacing of the first peak in the HT and the HTlc's doublet peak (the 110 plane). For catalyst A, the $a$ parameter (Table 1), which is similar to that presented in the literature [19], was found to be $3.06 \AA$. The $c$ dimension corresponds to thrice the 003 plane $d$-spacing (Table 1) and is also in agreement with that reported in literature [19].

The solvent effect investigation demonstrated shorter reaction times with $\mathrm{MeCN} / \mathrm{H}_{2} \mathrm{O}$ and $t$ - $\mathrm{BuOH} / \mathrm{H}_{2} \mathrm{O}(1: 1 v / v)$ than toluene. Taking into consideration the dielectric constants of the $\beta$-amino alcohol, usually around 25 [26], the aminohydroxylation reaction is best carried out in a solvent system that exhibits a high dielectric constant. $\mathrm{MeCN} /$ water $(1: 1 v / v)$ and $t-\mathrm{BuOH} /$ water $(1: 1 v / v)$ exhibit 
a higher dielectric constant than toluene $\left(55.69\right.$ at $25^{\circ} \mathrm{C}$ and 47.94 at $60{ }^{\circ} \mathrm{C}$ [26], and 36.59 at $20^{\circ} \mathrm{C}$ and 27.80 at $60{ }^{\circ} \mathrm{C}$ [27], respectively, vs. 2.38 at $25^{\circ} \mathrm{C}$ for toluene [20]). It is thus evident why both $\mathrm{MeCN} /$ water $(1: 1 v / v)$ and $t-\mathrm{BuOH} /$ water $(1: 1 v / v)$ exhibit a shorter reaction time than toluene. Longer reaction times may also be observed for toluene as a solvent system, because water hydrolysis enhances the formation of the $\beta$-amino alcohol and, unlike $\mathrm{MeCN}$ and $t$ - $\mathrm{BuOH}$, water is immiscible with toluene.

The versatility of the Os-HTlc catalyst in the dihydroxylation reaction with different olefins has been studied [19], showing $99.9 \%$ selectivity to diols, and it was found to be a truly heterogeneous system. The "ideal" composition of the Os-HTLc catalyst has also been investigated [20]. It was found that the $\mathrm{Os} / \mathrm{Zn} / \mathrm{Al}$ composition gives the most active catalyst in the dihydroxylation of cyclohexene, in terms of reaction time (for complete conversion of cyclohexene). The current results show that the Os-HTlc is active in the aminohydroxylation reaction with very high selectivity to the $\beta$-amino alcohols $(\sim 99.9 \%)$ of different olefin classes. The different classes of olefins only influence the reaction time (to complete olefin conversion), where functionalized olefins (Table 2, entry $4-7$ ) required $\sim 24 \mathrm{~h}$ reaction time. This could be the result of steric hindrance around the double bond limiting the interaction of the olefin and catalyst. This steric hindrance effect was also observed in the dihydroxylation reaction [19]. The results obtained showed slightly shorter reaction times for catalyst $B$, probably because of the much higher surface area (Table 1), which compensates for the lower Os content. However, catalyst $B$ gave significantly lower selectivity to the $\beta$-amino alcohols, with a rise in diol formation. This could be attributed to the loss of the HTlc structure.

The heterogeneity of the aminohydroxylation over Os-HTlc was investigated in term of Os leaching and catalyst recyclability under different reaction conditions. The solvent system influenced the Os leaching (in inactive form) level. This could be attributed to the chloramine-T solubility and its polarization effect, and/or the small amount of leached Os is the result of surface Os that was not fully incorporated in the HTlc structure. It is noteworthy that the leached Os is inactive and the aminohydroxlation reaction only occurs over the Os-HTlc catalyst. Reusability of the catalyst was a key aspect of this study in order to minimize the economic and environmental cost of Os on the process. Table 3 shows the reaction time (to complete olefin conversion) increased slightly from the first to third cycle, with no change to the $\beta$-amino alcohol yield (i.e., $>99 \%$ ) as a function of cycle number. This slight effect may be the result of the leaching of osmium or, more likely, a slow loss of HTlc structure. Some catalysts with a "better" HTlc structure are known to react faster than those with defects, as demonstrated in the dihydroxylation reaction [20].

To investigate the impact of the aminohdroxylation reaction on the Os-HTlc catalyst, the spent catalyst was characterized by XRD and BET surface area measurement, to study phase changes/crystallinity and surface area, respectively. The XRD results (Figure 5) show that the HTlc structure of the catalyst is maintained after the reaction, however, the crystallinity of the catalyst dropped. The BET surface area analyses of the spent catalyst showed an increase in the surface area of the catalyst to $107 \mathrm{~m}^{2} / \mathrm{g}$, from $87 \mathrm{~m}^{2} / \mathrm{g}$ before the reaction (i.e., fresh catalyst). This change may be the result of grinding of the catalyst to a fine powder by the magnetic stirrer bar during the course of the reaction and/or redox processes on the catalyst's surface causing a potential loss of HTlc structure.

\section{Materials and Methods}

\subsection{Catalyst Preparation}

The preparation of the catalyst was carried out using the co-precipitation technique following a published method [12,13]. The salts $\mathrm{OsCl}_{3} \cdot n \mathrm{H}_{2} \mathrm{O}(0.53 \mathrm{~g}, 1.53 \mathrm{mmol}), \mathrm{ZnCl}_{2}$ (2.12 g, $\left.15.3 \mathrm{mmol}\right)$, and $\mathrm{AlCl}_{3} \cdot 6 \mathrm{H}_{2} \mathrm{O}(1.23 \mathrm{~g}, 5.10 \mathrm{mmol})$ were dissolved in $10 \mathrm{~mL}$ of de-ionized water. Sodium hydroxide solution $1 \mathrm{M}(46 \mathrm{~mL})$ was used to dissolve sodium bicarbonate $(1.41 \mathrm{~g}, 13.3 \mathrm{mmol})$. The two solutions (i.e., metals solution and base solution) were added drop-wise simultaneously into a $500 \mathrm{~mL}$ three necked round bottom flask, while the $\mathrm{pH}$ was maintained between 8 and 10. After complete addition 
of the solutions, the resulting mixture was heated to $65 \pm 5{ }^{\circ} \mathrm{C}$ for $18 \mathrm{~h}$. The solution was then allowed to cool to room temperature, after which the precipitate was filtered and washed to neutrality by large amounts of de-ionized water. Thereafter, the precipitate was dried in the oven for $12 \mathrm{~h}$ at $110{ }^{\circ} \mathrm{C}$ (catalyst A). Catalyst B was prepared by heat treating a sample of catalyst A under a nitrogen atmosphere at $300^{\circ} \mathrm{C}$ for $2 \mathrm{~h}$.

\subsection{Catalyst Characterization}

The metal ratio was determined by inductively coupled plasma optical emission spectroscopy (ICP-OES) utilizing a Perkin Elmer Precisely Optical Emission Spectrometer, Optima 5300 DV (PerkinElmer, Shelton, CT, USA). Powder XRD was carried out using a Bruker D8 Advance (Karlsruhe, Germany) with diffracplus XRD commander software (version 2.5, Bruker AXS, Billerica, MA, USA), and a Bruker VANTEC detector (Bruker, Karlsruhe, Germany). The radiation source used was $\mathrm{Cu} \mathrm{K} \alpha$ (wavelength of $0.1540 \mathrm{~nm}$ ), operating on a long focus line with a voltage and amperage of $40 \mathrm{kV}$ and $40 \mathrm{~mA}$, respectively. The surface area of the different catalysts was obtained using a Micromeritics Gemini instrument (Micrometrics, Atlanta, GA, USA). Infrared analyses of the catalysts were carried out using a Perkin Elmer Precisely, Universal Attenuated Total Reflection (ATR) spectrum 100 series (PerkinElmer, Shelton, CT, USA). The geometry around aluminum was determined by ${ }^{27} \mathrm{Al}$ solid state nuclear magnetic resonance (SS-NMR), utilizing a Bucker $600 \mathrm{MHz}$ Ultrashield instrument (Bruker, Karlsruhe, Germany), equipped with a 4 mm MAS BB/IH probe (Bruker, Karlsruhe, Germany) that was spinning at a speed of $12 \mathrm{kHz}$, with $1 \mathrm{~s}$ recycling speed. The dispersion of osmium in the catalyst was determined by scanning electron microscopy (SEM)-electron dispersion spectroscopy (EDS), utilizing a Jeol JSM-6100 scanning microscope (Joel, Peabody, MA, USA) with a Bruker signal processing unit detector (Bruker, Karlsruhe, Germany).

\subsection{Catalytic Activity}

\subsubsection{Standard Catalytic Testing Method}

The aminohydroxylation reaction was carried out by adding $6 \mathrm{~mL}$ of solvent to a $\mathrm{N}_{2}$ filled Schlenk tube, followed by the addition of the olefin $(0.478 \mathrm{mmol})$, nitrogen source (chloramine-T) $(2 \mathrm{eq}$, $0.2173 \mathrm{~g})$, and the catalyst $(0.03 \mathrm{~g})$, in this respective order. The reaction was monitored by a Perkin Elmer Autosystem XL gas chromatograph (PerkinElmer, Shelton, CT, USA) with a flame ionization detector (GC-FID), equipped with a CB Sil5 column, until complete depletion of the starting material (olefin). The $\beta$-amino alcohols have high boiling points; therefore, the products were analysed by a Shimadzu LC-8A high performance liquid chromatograph (Shimadzu, Kyoto, Japan) (HPLC) equipped with a $\mathrm{C} 8$ column and an ultra-violet detector. Each aminohydroxylation product was isolated and fully characterised $\left({ }^{1} \mathrm{H}\right.$ and ${ }^{13} \mathrm{C}-\mathrm{NMR}, \mathrm{IR}$, and mass spectrometry (MS)). Each reaction was repeated a minimum of two times.

\subsubsection{Investigation into the Effect of the Solvent on the Reaction}

This study was carried out using three different solvents with different polarities. The solvents were toluene $(6 \mathrm{~mL}$ toluene and $172 \mu \mathrm{L}$ water), $t$-butanol/water $(1: 1 \mathrm{v} / v)$, and acetonitrile/water $(1: 1 v / v)$. The olefin used in this study was cyclohexene and catalyst A was utilised as the respective catalyst. The catalytic testing was carried out as described in Section 4.3.1.

\subsubsection{Investigation into the Effect of the Temperature on the Reaction}

This investigation was carried out as described in Section 4.3.1, employing three different temperatures (unless otherwise mentioned), namely, $25^{\circ} \mathrm{C}, 40^{\circ} \mathrm{C}$, and $60^{\circ} \mathrm{C}$. The olefin used in this part of the study was styrene and catalyst A was utilised as the respective catalyst. 
4.3.4. Investigation into the Effect of the Catalyst Structure on the Reaction

This investigation was carried out as described in Section 4.3.1., with catalysts A and B. The olefins used in this study were cyclohexene and $t$-butyl crotonate. The solvent utilized was acetonitrile/water $(1: 1 v / v)$, as described in Section 4.3.1.

\subsection{5. $\beta$-Amino Alcohols Product Characterization}

$\mathrm{N}$-(2-hydroxycyclohexyl)-4-methylbenzenesulfonamide ( $\beta$-amino alcohol of cyclohexene, $23 \%$ and $25 \%$ isolated yield in $t-\mathrm{BuOH} / \mathrm{H}_{2} \mathrm{O}$ and $\mathrm{MeCN} / \mathrm{H}_{2} \mathrm{O}$, respectively)

${ }^{1} \mathrm{H}$ NMR $\left(400 \mathrm{MHz}, \mathrm{CDCl}_{3}\right): \delta 1.5-1.72(\mathrm{~m}, 8 \mathrm{H}), 2.44(\mathrm{~s}, 3 \mathrm{H}), 3.21(\mathrm{~m}, 1 \mathrm{H}), 3.78(\mathrm{~d}, J=2.48 \mathrm{~Hz}, 1 \mathrm{H}), 4.80$ $(\mathrm{d}, J=7.48 \mathrm{~Hz}, 1 \mathrm{H}), 7.32(\mathrm{~d}, J=8.04 \mathrm{~Hz}, 2 \mathrm{H}), 7.79(\mathrm{~d}, J=8.24 \mathrm{~Hz}, 2 \mathrm{H}) \cdot{ }^{13} \mathrm{C} \mathrm{NMR}\left(100 \mathrm{MHz}, \mathrm{CDCl}_{3}\right)$ $\delta 19.7(\mathrm{~s}, 1 \mathrm{C}), 21.5(\mathrm{~s}, 1 \mathrm{C}), 23.3(\mathrm{~s}, 1 \mathrm{C}), 27.9(\mathrm{~s}, 1 \mathrm{C}), 31.4(\mathrm{~s}, 1 \mathrm{C}), 55.1(\mathrm{~s}, 1 \mathrm{C}), 68.7(\mathrm{~s}, 1 \mathrm{C}), 126.9(\mathrm{~s}, 2 \mathrm{C}), 129.7$ $(\mathrm{s}, 2 \mathrm{C}), 137.9(\mathrm{~s}, 1 \mathrm{C}), 143.3(\mathrm{~s}, 1 \mathrm{C}) . \mathrm{IR}\left(\mathrm{cm}^{-1}\right)=3414(\mathrm{~m}),(\mathrm{OH}), 3137(\mathrm{~m}),(\mathrm{NH}), 2938(w),\left(\mathrm{CH}_{2}\right), 2849(w)$, $\left(\mathrm{CH}_{3}\right), 1598(\mathrm{~m}),(\mathrm{Ar}), 1029(\mathrm{~m}),(\mathrm{S}=\mathrm{O})$. Mass calculated $=269, \mathrm{MS}=291 \mathrm{~m} / z(\mathrm{M}+\mathrm{Na})$.

$\mathrm{N}$-(hydroxyhexan-2-yl)-4-methylbenzenesulfonamide ( $\beta$-amino alcohol of hexene, $8 \%$ and $8 \%$ isolated yield in $t-\mathrm{BuOH} / \mathrm{H}_{2} \mathrm{O}$ and $\mathrm{MeCN} / \mathrm{H}_{2} \mathrm{O}$, respectively)

${ }^{1} \mathrm{H}$ NMR $\left(400 \mathrm{MHz}, \mathrm{CDCl}_{3}\right) \delta 0.87(\mathrm{t}, J=6.86 \mathrm{~Hz}, 3 \mathrm{H}), 1.2-1.40(\mathrm{~m}, 6 \mathrm{H}), 2.42(\mathrm{~s}, 3 \mathrm{H}), 2.7-2.80(\mathrm{~m}, 1 \mathrm{H})$, 3.0-3.01 (m, 1H), 3.6-3.70 (m, 1H), $7.31(\mathrm{~d}, J=8.04 \mathrm{~Hz}, 2 \mathrm{H}), 7.74(\mathrm{~d}, J=8.20 \mathrm{~Hz}, 2 \mathrm{H}) .{ }^{13} \mathrm{C}$ NMR $(100 \mathrm{MHz}$, $\left.\mathrm{CDCl}_{3}\right) \delta 13.9(\mathrm{~s}, 1 \mathrm{C}), 21.5(\mathrm{~s}, 1 \mathrm{C}), 22.5(\mathrm{~s}, 1 \mathrm{C}), 27.4(\mathrm{~s}, 1 \mathrm{C}), 34.3(\mathrm{~s}, 1 \mathrm{C}), 48.6(\mathrm{~s}, 1 \mathrm{C}), 70.4(\mathrm{~s}, 1 \mathrm{C}), 127.1(\mathrm{~s}, 2 \mathrm{C})$, $129.7(\mathrm{~s}, 2 \mathrm{C}), 136.7(\mathrm{~s}, 1 \mathrm{C}), 143.5(\mathrm{~s}, 1 \mathrm{C})$. Mass calculated $=271.1, \mathrm{MS}=293.1 \mathrm{~m} / \mathrm{z}(\mathrm{M}+\mathrm{Na})$.

$N$-(-2hydroxyl-1-phenylethyl)-4-methylbenzenesulfonamide ( $\beta$-amino alcohol of Styrene, $13 \%$ and $14 \%$ isolated yield in $t-\mathrm{BuOH} / \mathrm{H}_{2} \mathrm{O}$ and $\mathrm{MeCN} / \mathrm{H}_{2} \mathrm{O}$, respectively)

${ }^{1} \mathrm{H}$ NMR $\left(400 \mathrm{MHz}, \mathrm{CDCl}_{3}\right) \delta 2.42(\mathrm{~s}, 3 \mathrm{H}), 3.0-3.03(\mathrm{~m}, 1 \mathrm{H}), 3.2-3.29(\mathrm{~m}, 1 \mathrm{H}), 4.79(\mathrm{~d}, J=4.40 \mathrm{~Hz}, 1 \mathrm{H})$, $4.89(\mathrm{~d}, J=4.40 \mathrm{~Hz}, 1 \mathrm{H}), 7.2-7.34(\mathrm{~m}, 7 \mathrm{H}), 7.72(\mathrm{~d}, J=8.28 \mathrm{~Hz}, 2 \mathrm{H}) .13 \mathrm{C} \mathrm{NMR}\left(100 \mathrm{MHz}, \mathrm{CDCl}_{3}\right) \delta$ $21.5(\mathrm{~s}, 1 \mathrm{C}), 30.9(\mathrm{~s}, 1 \mathrm{C}), 50.1(\mathrm{~s}, 1 \mathrm{C}), 125.8(\mathrm{~s}, 2 \mathrm{C}), 127.1(\mathrm{~s}, 2 \mathrm{C}), 128.3(\mathrm{~s}, 1 \mathrm{C}), 128.7(\mathrm{~s}, 2 \mathrm{C}), 129.8(\mathrm{~s}, 2 \mathrm{C}), 136.7$ $(\mathrm{s}, 1 \mathrm{C}), 140.7(\mathrm{~s}, 1 \mathrm{C}), 143.6(\mathrm{~s}, 1 \mathrm{C})$. IR $\left(\mathrm{cm}^{-1}\right)=3399(\mathrm{~m}),(\mathrm{OH}), 3149(\mathrm{~m}),(\mathrm{NH}), 2926(w),\left(\mathrm{CH}_{2}\right), 2862(w)$, $\left(\mathrm{CH}_{3}\right), 1599(w),(\mathrm{Ar}), 1086(\mathrm{~m}),(\mathrm{S}=\mathrm{O})$. Mass calculated $=291, \mathrm{MS}=313 \mathrm{~m} / z(\mathrm{M}+\mathrm{Na})$.

$\mathrm{N}$-(2-hydroxyl-1,2-diphenylethyl)-4-methylbenzenesulfonamide ( $\beta$-amino alcohol of cis-stilbene, 30\% and $30 \%$ isolated yield in $t-\mathrm{BuOH} / \mathrm{H}_{2} \mathrm{O}$ and $\mathrm{MeCN} / \mathrm{H}_{2} \mathrm{O}$, respectively)

${ }^{1} \mathrm{H}$ NMR (400 MHz, DMSO) $\delta 2.21(\mathrm{~s}, 3 \mathrm{H}), 4.28(\mathrm{dd}, J=6.80,9.20 \mathrm{~Hz}, 1 \mathrm{H}), 4.62(\mathrm{dd}, J=6.80,9.20 \mathrm{~Hz}$, $1 \mathrm{H}), 5.37(\mathrm{~d}, J=4.80 \mathrm{~Hz}, 1 \mathrm{H}), 7.0-7.29(\mathrm{~m}, 14 \mathrm{H}), 8.08(\mathrm{~d}, J=4.80 \mathrm{~Hz}, 1 \mathrm{H}) .{ }^{13} \mathrm{C}$ NMR $(100 \mathrm{MHz}, \mathrm{DMSO}) \delta$ $20.8(\mathrm{~s}, 1 \mathrm{C}), 63.3(\mathrm{~s}, 1 \mathrm{C}), 75.3(\mathrm{~s}, 1 \mathrm{C}), 126.1(\mathrm{~s}, 2 \mathrm{C}), 126.3(\mathrm{~s}, 1 \mathrm{C}), 126.7(\mathrm{~s}, 2 \mathrm{C}), 126.9(\mathrm{~s}, 1 \mathrm{C}), 127.0(\mathrm{~s}, 2 \mathrm{C}), 127.5$ $(\mathrm{s}, 2 \mathrm{C}), 128.2(\mathrm{~s}, 2 \mathrm{C}), 128.8(\mathrm{~s}, 2 \mathrm{C}), 138.5(\mathrm{~s}, 1 \mathrm{C}), 138.8(\mathrm{~s}, 1 \mathrm{C}), 141.6(\mathrm{~s}, 1 \mathrm{C}), 142.6(\mathrm{~s}, 1 \mathrm{C}) . \mathrm{IR}\left(\mathrm{cm}^{-1}\right)=3461(\mathrm{~m})$, $(\mathrm{OH}), 3323(\mathrm{~m}),(\mathrm{NH}), 3031(w), 1598(w),(\mathrm{Ar}), 1055(\mathrm{~m}),(\mathrm{S}=\mathrm{O})$. Mass calculated $=367.1, \mathrm{MS}=389.12 \mathrm{~m} / \mathrm{z}$ $(M+\mathrm{Na})$.

Methyl-2-hydroxy-3-(4-methylbenzenesulfonamide)-3-phenylpropanoate ( $\beta$-amino alcohol of methylcinnamate, $35 \%$ and $34 \%$ isolated yield in $t-\mathrm{BuOH} / \mathrm{H}_{2} \mathrm{O}$ and $\mathrm{MeCN} / \mathrm{H}_{2} \mathrm{O}$, respectively)

${ }^{1} \mathrm{H}$ NMR $\left(400 \mathrm{MHz}, \mathrm{CDCl}_{3}\right) \delta 2.32(\mathrm{~s}, 3 \mathrm{H}), 3.18(\mathrm{~d}, J=4.16 \mathrm{~Hz}, 1 \mathrm{H}), 3.75(\mathrm{~s}, 3 \mathrm{H}), 4.34(\mathrm{dd}, J=2.36$, $4.04 \mathrm{~Hz}, 1 \mathrm{H}), 4.85(\mathrm{dd}, J=2.22,9.70 \mathrm{~Hz}, 1 \mathrm{H}), 5.52(\mathrm{~d}, J=9.72 \mathrm{~Hz}, 1 \mathrm{H}), 7.0-7.18(\mathrm{~m}, 7 \mathrm{H}), 7.53(\mathrm{~d}$, $J=8.20 \mathrm{~Hz}, 2 \mathrm{H}) .{ }^{13} \mathrm{C} \mathrm{NMR}\left(100 \mathrm{MHz}, \mathrm{CDCl}_{3}\right) \delta 21.4(\mathrm{~s}, 1 \mathrm{C}), 53.2(\mathrm{~s}, 1 \mathrm{C}), 58.9(\mathrm{~s}, 1 \mathrm{C}), 74.2(\mathrm{~s}, 1 \mathrm{C}), 126.8$ $(\mathrm{s}, 2 \mathrm{C}), 126.9(\mathrm{~s}, 2 \mathrm{C}), 127.8(\mathrm{~s}, 2 \mathrm{C}), 128.4(\mathrm{~s}, 2 \mathrm{C}), 129.2(\mathrm{~s}, 1 \mathrm{C}), 137.4(\mathrm{~s}, 1 \mathrm{C}), 137.5(\mathrm{~s}, 1 \mathrm{C}), 143.1(\mathrm{~s}, 1 \mathrm{C}), 172.4$ $(\mathrm{s}, 1 \mathrm{C}) . \mathrm{IR}\left(\mathrm{cm}^{-1}\right)=3477(\mathrm{~m}),(\mathrm{OH}), 3139(\mathrm{~m}),(\mathrm{NH}), 2967(w),\left(\mathrm{CH}_{3}\right), 2882(w),\left(\mathrm{CH}_{3}\right), 1598(w),(\mathrm{Ar}), 1738$ $(m),(\mathrm{C}=\mathrm{O}), 1056(\mathrm{~m}),(\mathrm{S}=\mathrm{O})$. Mass calculated $=349.3, \mathrm{MS}=372 \mathrm{~m} / \mathrm{z}(\mathrm{M}+\mathrm{Na})$.

Dimethyl-2-hydroxy-3-(4-methylbenzenesulfonamide)succinate ( $\beta$-amino alcohol of dimethylfumarate, $30 \%$ and $31 \%$ isolated yield in $t-\mathrm{BuOH} / \mathrm{H}_{2} \mathrm{O}$ and $\mathrm{MeCN} / \mathrm{H}_{2} \mathrm{O}$, respectively) 
${ }^{1} \mathrm{H}$ NMR $\left(400 \mathrm{MHz}, \mathrm{CDCl}_{3}\right) \delta 2.41(\mathrm{~s}, 3 \mathrm{H}), 3.23(\mathrm{~d}, J=5.20 \mathrm{~Hz}, 1 \mathrm{H}), 3.60(\mathrm{~s}, 3 \mathrm{H}), 3.76(\mathrm{~s}, 3 \mathrm{H}), 4.39(\mathrm{dd}$, $J=1.92,9.80 \mathrm{~Hz}, 1 \mathrm{H}), 4.59(\mathrm{dd}, J=1.78,5.02 \mathrm{~Hz}, 1 \mathrm{H}), 5.37(\mathrm{~d}, J=9.88 \mathrm{~Hz}, 1 \mathrm{H}), 7.29(\mathrm{~d}, J=8.20 \mathrm{~Hz}, 2 \mathrm{H})$, $7.70(\mathrm{~d}, J=8.28 \mathrm{~Hz}, 2 \mathrm{H}) .{ }^{13} \mathrm{C}$ NMR $\left(100 \mathrm{MHz}, \mathrm{CDCl}_{3}\right) \_21.5(\mathrm{~s}, 1 \mathrm{C}), 53.1(\mathrm{~s}, 1 \mathrm{C}), 53.4(\mathrm{~s}, 1 \mathrm{C}), 57.9(\mathrm{~s}, 1 \mathrm{C}), 71.5$ $(\mathrm{s}, 1 \mathrm{C}), 127.2(\mathrm{~s}, 2 \mathrm{C}), 129.6(\mathrm{~s}, 2 \mathrm{C}), 136.5(\mathrm{~s}, 1 \mathrm{C}), 143.8(\mathrm{~s}, 1 \mathrm{C}), 168.7(\mathrm{~s}, 1 \mathrm{C}), 171.3(\mathrm{~s}, 1 \mathrm{C}) . \mathrm{IR}\left(\mathrm{cm}^{-1}\right)=3503$ $(m),(\mathrm{OH}), 3260(m),(\mathrm{NH}), 2923(w), 1598(w),(\mathrm{Ar}), 1738(m), 1730(m),(\mathrm{C}=\mathrm{O}), 1056(m),(\mathrm{S}=\mathrm{O})$. Mass calculated $=331, \mathrm{MS}=353 \mathrm{~m} / \mathrm{z}(\mathrm{M}+\mathrm{Na})$.

tert-Butyl-2-hydroxy-3-(4-methylbenzenesulfonamide)butanoate ( $\beta$-amino alcohol of tert-butylcrotonate, $32 \%$ and $32 \%$ isolated yield in $t-\mathrm{BuOH} / \mathrm{H}_{2} \mathrm{O}$ and $\mathrm{MeCN} / \mathrm{H}_{2} \mathrm{O}$, respectively)

${ }^{1} \mathrm{H}$ NMR $\left(400 \mathrm{MHz}, \mathrm{CDCl}_{3}\right) \delta 0.98(\mathrm{~d}, J=6.72 \mathrm{~Hz}, 3 \mathrm{H}), 1.51(\mathrm{~s}, 9 \mathrm{H}), 2.41(\mathrm{~s}, 3 \mathrm{H}), 3.22(\mathrm{~d}, J=3.64 \mathrm{~Hz}$, $1 \mathrm{H}), 3.8-3.86(\mathrm{~m}, 2 \mathrm{H}), 4.75(\mathrm{~d}, J=10.08 \mathrm{~Hz}, 1 \mathrm{H}), 7.29(\mathrm{~d}, J=7.96 \mathrm{~Hz}, 2 \mathrm{H}), 7.75(\mathrm{~d}, J=8.32 \mathrm{~Hz}, 2 \mathrm{H}) .{ }^{13} \mathrm{C}$ NMR (100 MHz, CDCl $\mathrm{CD}_{3} \delta 17.9(\mathrm{~s}, 1 \mathrm{C}), 21.5(\mathrm{~s}, 1 \mathrm{C}), 27.9(\mathrm{~s}, 3 \mathrm{C}), 51.5(\mathrm{~s}, 1 \mathrm{C}), 73.6(\mathrm{~s}, 1 \mathrm{C}), 84.1(\mathrm{~s}, 1 \mathrm{C}), 126.9$ $(\mathrm{s}, 2 \mathrm{C}), 129.7(\mathrm{~s}, 2 \mathrm{C}), 138.6(\mathrm{~s}, 1 \mathrm{C}), 143.3(\mathrm{~s}, 1 \mathrm{C}), 171.6(\mathrm{~s}, 1 \mathrm{C}) . \mathrm{IR}\left(\mathrm{cm}^{-1}\right)=3446(\mathrm{~m}),(\mathrm{OH}), 3260(\mathrm{~m}),(\mathrm{NH})$, $2985(w),(\mathrm{Ar}), 2919(w),\left(\mathrm{CH}_{3}\right), 1598(w),(\operatorname{ar}), 1716(m),(\mathrm{C}=\mathrm{O}), 1048(m),(\mathrm{S}=\mathrm{O})$. Mass calculated = 329, $\mathrm{MS}=351 \mathrm{~m} / z(\mathrm{M}+\mathrm{Na})$.

\subsection{Leaching Test}

This study was carried out in two solvent systems, $\mathrm{MeCN} /$ water $(1: 1 v / v)$ and $t$ - $\mathrm{BuOH} /$ water $(1: 1 v / v)$ (Section 4.3.1). The catalyst used was catalyst A and cyclohexene was the olefin. However, the reaction was stopped after approximately $20 \%$ conversion of cyclohexene $(3 \mathrm{~h})$. Thereafter, the catalyst was removed by gravity filtration and the reaction mixture was centrifuged at $3000 \mathrm{rpm}$ for $15 \mathrm{~min}$, for the removal of any suspended fine catalyst particles in the reaction mixture. The reaction solution was then stirred until the end of the normal duration that the reaction takes in the presence of the catalyst. At the end of this period, GC analysis was undertaken to investigate if any further conversion of the starting material had occurred in the absence of the catalyst, as well as to determine if any osmium that may have leached was catalytically active or not. Furthermore, to determine if any osmium leached from the catalyst, ICP-OES analysis of the solution was undertaken.

\subsection{Recycling Test}

For the determination of the reusability of the catalyst, it was recycled three times. The reaction was carried out as described in Section 2.3. At the end of the reaction, the catalyst was filtered by vacuum filtration and reused with fresh starting material, that is, olefin (cyclohexene), nitrogen source (chloramine-T) (2 eq), and solvent system (i.e., $\mathrm{MeCN} /$ water $(1: 1 v / v)$.

\section{Conclusions}

The aminohydroxylation reaction can be carried out heterogeneously using hydrotalcite-like catalysts containing osmium. Importantly, this catalyst also gave a very high selectivity to the aminohydroxylation products and, consequently, a very low selectivity to the diols, unlike other catalysts in literature. Indeed, only trace quantities of diol were observed. Functionalised and electron deficient olefins showed the longest reaction times. Characterisation of the spent catalyst showed that the catalyst maintained the hydrotalcite-like structure after the reaction. This study has shown the lowest amount of osmium leach reported yet. Furthermore, it is possible that the use of a different nitrogen source may eliminate leaching altogether. We further suggest that using a chiral nitrogen source or ligand may allow for an asymmetric reaction.

Author Contributions: M.I.F. carried out all the experimental work and original manuscript preparation. G.E.M.M. and H.B.F. acted in supervision roles, validating and reviewing the manuscript.

Funding: This research was funded by Mintek (AMI program) and the South African Department of Science and Technology (DST).

Acknowledgments: The Electron Microscopy Unit at UKZN, Westville is thanked for the SEM and SEM-EDS analyses. 
Conflicts of Interest: The authors report no conflict of interest.

\section{References}

1. Kolb, H.C.; Sharpless, K.B. Asymmetric aminohydroxylation. In Transition Metals for Organic Synthesis; Matthias Beller, C.B., Ed.; Wiley-VCH: Weinheim, Germany, 1998.

2. Kolb, H.C.; VanNieuwenhze, M.S.; Sharpless, K.B. Catalytic asymmetric dihydroxylation. Chem. Rev. 1994, 94, 2483-2547. [CrossRef]

3. Dupau, P.; Epple, R.; Thomas, A.A.; Fokin, V.V.; Sharpless, K.B. Osmium-catalyzed dihydroxylation of olefins in acidic media: Old process, new tricks. Adv. Synth. Catal. 2002, 344, 421-433. [CrossRef]

4. Li, G.; Chang, H.-T.; Sharpless, K.B. Catalytic asymmetric aminohydroxylation (aa) of olefins. Angew. Chem. Int. Ed. Engl. 1996, 35, 451-454. [CrossRef]

5. Li, G.; Angert, H.H.; Sharpless, K.B. N-halocarbamate salts lead to more efficient catalytic asymmetric aminohydroxylation. Angew. Chem. Int. Ed. Engl. 1996, 35, 2813-2817. [CrossRef]

6. Nilov, D.; Reiser, O. The sharpless asymmetric aminohydroxylation-Scope and limitation. Adv. Synth. Catal. 2002, 344, 1169-1173. [CrossRef]

7. Bergmeier, S.C. The synthesis of vicinal amino alcohols. Tetrahedron 2000, 56, 2561-2576. [CrossRef]

8. Lohray, B.B.; Thombare, P.S.; Bhushan, V. Advances in asymmetric aminhydroxylation. PINSA 2002, 68A, 391.

9. Kattamuri, P.V.; Salmonsen, R.; McQuain, C.; Burstein, S.; Sun, H.; Li, G. Asymmetric synthesis of novel n-(1-phenyl-2,3-dihydroxypropyl)arachidonylamides and evaluation of their anti-inflammatory activity. Life Sci. 2013, 92, 506-511. [CrossRef] [PubMed]

10. Williamson, K.S.; Yoon, T.P. Iron-catalyzed aminohydroxylation of olefins. J. Am. Chem. Soc. 2010, 132, 4570-4571. [CrossRef] [PubMed]

11. Michaelis, D.J.; Shaffer, C.J.; Yoon, T.P. Copper(ii)-catalyzed aminohydroxylation of olefins. J. Am. Chem. Soc. 2007, 129, 1866-1867. [CrossRef] [PubMed]

12. Song, C.; Oh, C.; Lee, S.; Sherrington, D. Heterogeneous asymmetric aminohydroxylation of alkenes using a silica gel-supported bis-cinchona alkaloid. Chem. Commun. 1998, 22, 2435-2436. [CrossRef]

13. Mandoli, A.; Pini, D.; Agostini, A.; Salvadori, P. Heterogeneous asymmetric catalytic aminohydroxylation promoted by a bis-cinchona alkaloid derivative supported onto an insoluble organic polymeric matrix. Tetrahedron Asymmetry 2000, 11, 4039-4042. [CrossRef]

14. Choudary, B.M.; Chowdari, N.S.; Jyothi, K.; Kantam, M.L. Heterogeneous catalytic asymmetric aminohydroxylation of olefins using ldh-supported oso4. J. Mol. Catal. A Chem. 2003, 196, 151-156. [CrossRef]

15. Vaccari, A. Preparation and catalytic properties of cationic and anionic clays. Catal. Today 1998, 41, 53-71. [CrossRef]

16. Cavani, F.; Trifirò, F.; Vaccari, A. Hydrotalcite-type anionic clays: Preparation, properties and applications. Catal. Today 1991, 11, 173-301. [CrossRef]

17. Othman, M.R.; Helwani, Z.; Fernando, W.J.N. Synthetic hydrotalcites from different routes and their application as catalysts and gas adsorbents: A review. Appl. Organomet. Chem. 2009, 23, 335-346. [CrossRef]

18. Oswald, H.R.; Asper, R. Physics and Chemistry of Materials with Layered Structures; Reidel: Dordrecht, The Netherlands, 1977; Volume 73.

19. Friedrich, H.B.; Govender, M.; Makhoba, X.; Ngcobo, T.D.; Onani, M.O. The os/cu-al-hydrotalcite catalysed hydroxylation of alkenes. Chem. Commun. 2003, 23, 2922-2923. [CrossRef]

20. Naicker, T.; Datye, A.K.; Friedrich, H.B. A comparative study of os-hydrotalcites for the cis-dihydroxylation of cyclohexene. Appl. Catal. A Gen. 2008, 350, 96-102. [CrossRef]

21. Miyata, S. Hydrotalcites in relation to composition. Clays Clay Miner. 1980, 28, 50-56. [CrossRef]

22. Kosower, E.M. The effect of solvent on spectra. I. A new empirical measure of solvent polarity: Z-values. J. Am. Chem. Soc. 1958, 80, 3253-3260. [CrossRef]

23. Sheldon, R.A.; Wallau, M.; Arends, I.W.C.E.; Schuchardt, U. Heterogeneous catalysts for liquid-phase oxidations: Philosophers' stones or trojan horses? Acc. Chem. Res. 1998, 31, 485-493. [CrossRef]

24. Yang, X.-W.; Liu, H.-Q.; Xu, M.-H.; Lin, G.-Q. A highly efficient and practical new peg-bound bi-cinchona alkaloid ligand for the catalytic asymmetric aminohydroxylation of alkenes. Tetrahedron Asymmetry 2004, 15, 1915-1918. [CrossRef]

25. Hagen, J. Industrial Catalysis: A Practical Approach; Wiley-VCH: Weinheim-Hohensachsen, Germany, 2006. 
26. Gagliardi, L.G.; Castells, C.B.; Ràfols, C.; Rosés, M.; Bosch, E. Static dielectric constants of acetonitrile/water mixtures at different temperatures and debye-hückel a and a0b parameters for activity coefficients. J. Chem. Eng. Data 2007, 52, 1103-1107. [CrossRef]

27. Akerlof, G. Dielectric constants of some organic solvent-water mixtures at various temperatures. J.Am. Chem. Soc. 1932, 54, 4125-4139. [CrossRef] 